\title{
Remote Sensing Analysis Using Landsat 8 Data For Lithological Mapping - A Case Study In Mount Penanggungan, East Java, Indonesia
}

\author{
Hendra Bahar ${ }^{1}$, and Muhammad Taufik ${ }^{2}$
}

\begin{abstract}
Mount Penanggungan is one of the volcanoes that located in East Java Province, Indonesia, with the current status is a sleeping volcano. Although Mount Penanggungan is not active, it still make an interesting investigation in geological survey, especially to identify the lithological units, due that less researchers took place in Mount Penanggungan. Geological survey and investigaton can describes the information about physically condition of some land or region, with the result is Lithological Map of Mount Penanggungan. Remote sensing imagery, such as Landsat 8 Satellite imagery data series has been used widely in geology for mapping lithology in general. Remote sensing provides information of the properties of the surface exploration targets that is potential in mapping lithological units. Remote sensing technique are one of the standard procedures in exploration geology, due to it is high efficiency and low cost. Lithological mapping in Mount Penanggungan area is carried out by using Landsat 8 Satellite imagery data with image enhancement techniques, including RGB (red, green, blue) band composite, and combine it with Indonesian Surface Map data that will makes an existing Lithological Map of Mount Penanggungan. The results of this study showed the distribution of the lithological units in Mount Penanggungan, which the units are; vulcanic breccia, tuff breccia, and andesitic lava.
\end{abstract}

Keywords- volcano, geology, exploration, satellite, imagery, enhancement.

\section{INTRODUCTION}

Lithological mapping are the process to create an information about physical characters of Earth component, especially it lithology components. Lithological mapping of Mount Penanggungan will be done effectively if use the efficience method, accordings that Mount Penanggungan have an huge area. The suitable method is remote sensing technology.

Remote sensing data from space-and air-borne sensors have been widely applied to lithological mapping. There is a significant body of remote sensing literature that describes various data sets and image processing techniques that are used in geologic remote sensing, in particular for lithological analysis[3].

Remote sensing provides information of the properties of the surface exploration targets that is potential in mapping lithological units. Remote sensing technique are one of the standard procedures in exploration geology, due to it is high efficiency and low cost [2].

This study will use remote sensing imagery data from Landsat 8 Satellite, and then overlay it with Indonesian Surface Map data. The results of this study will show the distribution of the lithological units in Mount Penanggungan.

${ }^{1}$ Hendra Bahar, Department of Geological Engineering, Institut Teknologi Adhi Tama Surabaya (ITATS), Surabaya, 60117, Indonesia. E-mail: hendrabahar@gmail.com.

\section{METHOD}

Top of Mount Penanggungan are 1.653 meters from sea level, located in East Java Province, Indonesia, between 2 (two) district, Mojokerto District in western part, and Pasuruan District in eastern part. Latitude is 0 $7^{\circ} 36^{\prime} 50^{\prime \prime}$ of South Latitude and longitude is $112^{\circ} 37^{\prime} 10^{\prime \prime}$ of East Longitude.

Data that be use in this study are; Geological Map of Malang Sheet scale 1:100.000, Indonesian Surface Map scale 1:25.000, and Landsat 8 Satellite imagery data.

The Landsat 8 image used in this study (path 118 and row 65) was captured on October 22nd, 2015 under excellent weather conditions ( $<10 \%$ of cloud cover). The image was downloaded in a package containing 11 band images (in GeoTIFF).

\section{A. Reflectance conversion}

The Landsat 8 imagery data must be conversion first before use in analysis. Level 1T images of Landsat 8 consist of Digital Numbers (DN) lacking physically meaningful units. They were converted to reflectance, representing the ratio of the radiation reflected off a surface to the radiation striking it. This conversion is commonly needed for quantitative remote sensing as it accounts for solar conditions (illumination, geometry, and intensity) when the images were acquired [4]. This conversion of reflectance also called top of atmosphere (TOA)

There are two steps to do to have the TOA reflectance, the fistt step is conversion of DN to TOA reflectance, the second step is conversion of TOA reflectance to TOA reflectance that

conversion of DN to TOA reflectance $(\rho \lambda)$

$\rho \lambda=M_{\rho} Q_{\text {cal }}+A_{\rho}$

whereas:

$\rho \lambda=$ TOA reflectance, without sun angle correction

$M_{\rho} \quad=$ Band-specific multiplicative rescaling factor

$A_{\rho} \quad=$ Band-specific additive rescaling factor

$Q_{c a l} \quad=$ Quantized and calibrated standard product pixel values (DN)

conversion of TOA reflectance to TOA reflectance that had correction $\left(\rho \lambda^{*}\right)$

$\rho \lambda^{*}=\rho \lambda \% \cos \left(\theta_{S Z}\right)$

or

${ }^{2}$ Muhammad Taufik, Department of Geomatics Engineering, Institut Teknologi Sepuluh Nopember (ITS), Surabaya, 60111, Indonesia. Email: taufik_srmd@yahoo.com 


$$
\rho \lambda \varkappa \sin \left(\theta_{S E}\right)
$$

whereas:

$\rho \lambda^{*}=$ TOA reflectance, with sun angle correction

$\rho \lambda^{\prime} \quad=$ TOA reflectance, without sun angle correction

$\theta_{S e}=$ Sun elevation angle

\section{B. Color composite}

After having TOA reflectance with correction of Landsat 8 imagery data, the next step is image enhancement, which technique that be use is color composite.

The creation of false color composite is based on known spectral properties of rocks and alteration minerals in relation to the selected spectral bands, for clay and carbonate minerals, have absorption features from 2.1 to $2.4 \mathrm{um}$ and reflectance from 1.55 to $1.75 \mathrm{um}$ [1].

Color composite used in this paper are band 6 , band 5 , and band 7 as red, green, blue (RGB) from Landsat 8 imagery data that had been correction as TOA reflectance, see Fig.1.

\section{Map overlay}

Geological Map of Malang Sheet, and Indonesian Surface Map are use to make basemap that contains information about streams pattern, regional geology, and morphology around Mount Penanggungan.

Basemap above than get overlay with the result of color composite of Landsat 8 imagery data. Then use the unsupervised classification from the the result of overlay above. This map overlay analysis using ArcGIS software that had develop from Environment Science and Research Institute (ESRI), called ArcMap 10.1

The result of classification from overlay maps above will makes some zone of litological units that took place around Mount Penanggungan.
Next step is cropping the overlay result according to the region of Mount Penanggungan. The final result is the Lithological Map of Mount Penanggungan.

\section{RESULTS AND DISCUSSION}

The results from color composite technique of Landsat 8 imagery data that had used band 6 , band 5 , and band 7 as red, green, blue (RGB) showed good results in term of lithological mapping.

The lithological units can be devide into 3 (three) diffrence classes, they are; vulcanic breccia, tuff breccia, and andesitic lava (Fig.2).

\section{A. Vulcanic breccia}

Vulcanic breccia showed dark purple color, coarse texture, which the litologi material came from piroclastic flow from top peak of Mount Penanggungan. Vulcanic breccia can be devide into Arjuna-Welirang Vulcanic Breccia, and Penanggungan Vulcanic Breccia, accordings to it is surrounding area name.

\section{B. Tuff breccia}

Tuff breccia showed more variated color from purple, white, and green, little coarse texture, which the litologi material came from piroclastic of Mount Penanggungan. Tuff breccia can be name Penanggungan Tuff Breccia accordings to it is surrounding area name.

\section{Andesitic lava}

Andesitic lava showed variated color from dark purple to light purple, little soft texture, which the litologi material came from lava flow of Mount Penanggungan. Andesitic lava can be devide into Bekel Andesitic Lava, Bendo Andesitic Lava, Gajahmungkur Andesitic Lava, Genting Andesitic Lava, Jambi Andesitic Lava, Penanggungan Andesitic Lava, and Wangi Andesitic Lava

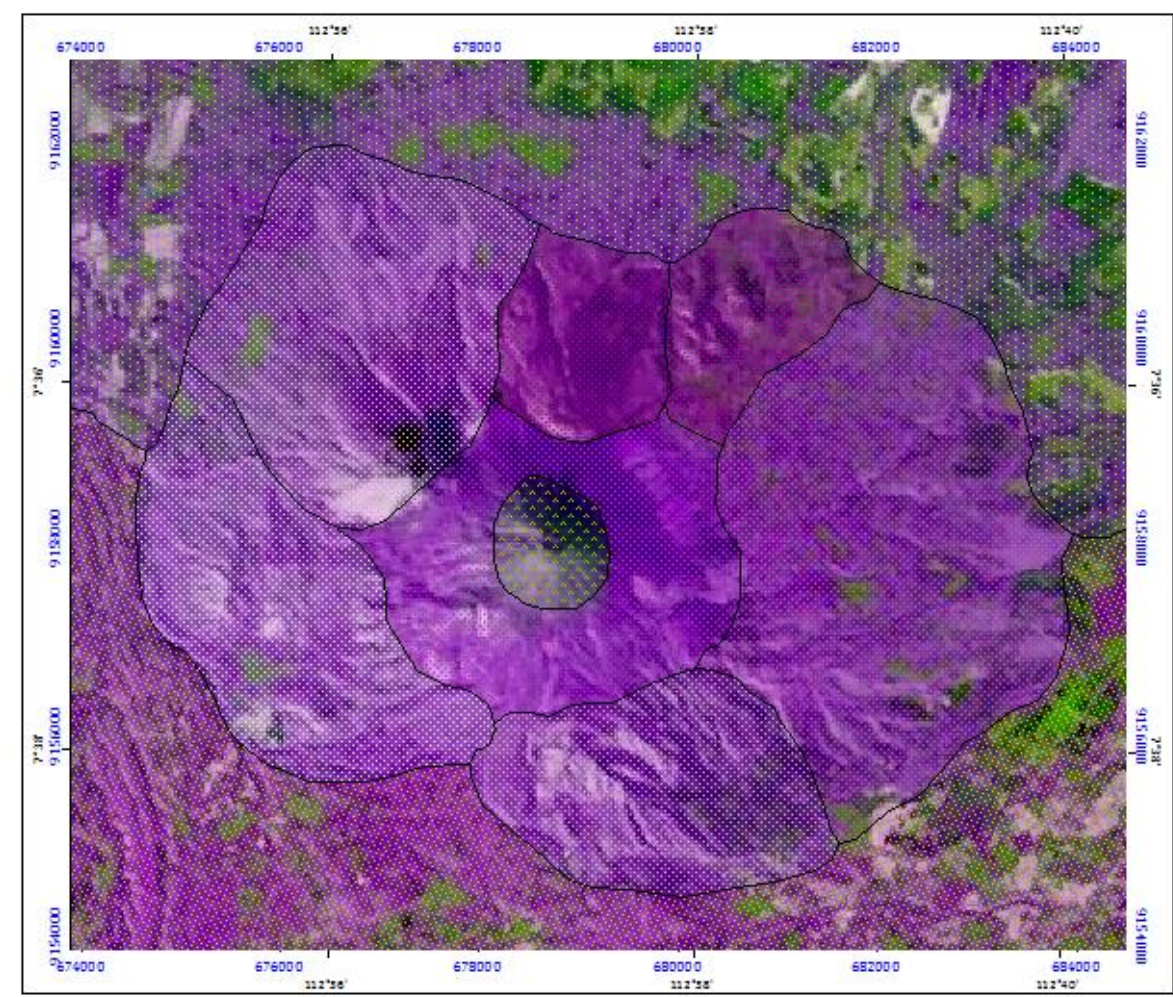

Figure. 1. Color Composite (6, 5 and 7 as RGB) of Landsat 8 Imagery Data 


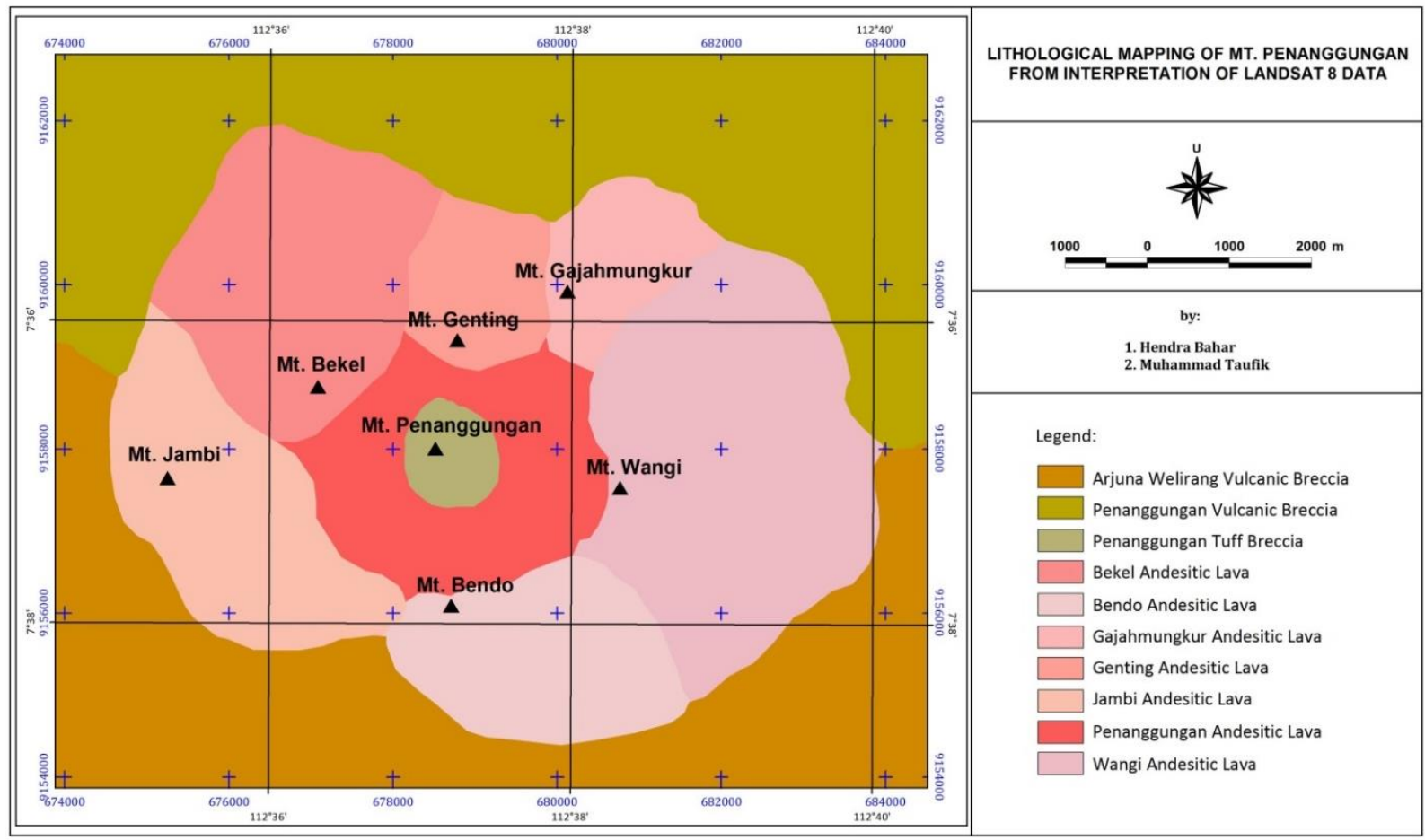

Figure. 2. Lithological Map of Mount Penanggungan, East Java, Indonesia

\section{CONCLUSION}

The purpose of this paper are to use remote sensing technique for analysis the lithological units of some areas, to made the lithological mapping, base on Landsat 8 imagery data, and can be uses as guidence for the researcher before investigating detail lithological characteristic of some places.

From the results, they are three lithological units can be showed; vulcanic breccia, tuff breccia, and andesitic lava, as the major lithology that consist around of Mount Penanggungan.

\section{REFERENCES}

[1] Ali, A.S.O., and Pour, A.B., "Lithological Mapping and Hydrothermal Alteration using Landsat 8 Data: A Case Study Ariab Mining District, Red Sea Hills, Sudan”, International Journal of Basic and Applied Sciences, Science Publishing Corp, 2014.

[2] Arunachalam, M., Udhayaraj, A.D., Jacob, A., NarenPrabakaran, V.P., Vasanth, M.S., and Saravanavel, J., "Hydrothermal Mineral Alteration Mapping in Parts of Northwestern Tamil Nadu, India - using Geospatial Technology", ISRS Proceeding Papers of Sort Interactive Session ISPRS TC VIII, InternationalSymposium on "Operational Remote Sensing Applications: Opportunities, Progress and Challenges", 2014.

[3] El-Leil, I.B., Soliman, N.M.A., and Elyaseer, M.H., "Lithological Classification of Neoproterozoic Rocks, Gabal El-Sabbagh Area, South East Sinai Egypt, using Support Vector Machine (SVM) Technique", IJISET-International Journal of Innovative Science, Engineering \& Technology, 2015.

[4] Han, T., and Nelson, JA., "Mapping Hydrothermally Altered Rocks with Landsat 8 Imagery: A Case Study in The KSM and Snowfield Zones, Northwestern British Columbia", British Columbia Geological Survey Paper, 2015.

[5] USGS, http://landsat.usgs.gov/band_designations Landsat_satellites.php (Accessed 2015-11-21). 